\title{
Effect of potassium salts in rats adapted to an acidogenic high-sulfur amino acid diet
}

\author{
Houda Sabboh, Marie-Noëlle Horcajada, Véronique Coxam, Jean-Claude Tressol, Catherine Besson, \\ Christian Rémésy and Christian Demigné* \\ Unité des Maladies Métaboliques et Micronutriments, INRA de Clermont-Ferrand/Theix and CRNH d'Auvergne, 63122 \\ St-Genès-Champanelle, France
}

(Received 19 April 2004 - Revised 22 February 2005 - Accepted 22 February 2005)

\begin{abstract}
Low-grade metabolic acidosis, consecutive to excessive catabolism of sulfur amino acids and a high dietary Na:K ratio, is a common feature of Western food habits. This metabolic alteration may exert various adverse physiological effects, especially on bone, muscle and kidneys. To assess the actual effects of various K salts, a model of the Westernised diet has been developed in rats: slight protein excess (20\% casein); cations provided as non-alkalinising salts; high Na: $\mathrm{K}$ ratio. This diet resulted in acidic urine ( $\mathrm{pH} 5 \cdot 5)$ together with a high rate of divalent cation excretion in urine, especially $\mathrm{Mg}$. Compared with controls, $\mathrm{K}$ supplementation as $\mathrm{KCl}$ accentuated $\mathrm{Ca}$ excretion, whereas potassium bicarbonate or malate reduced $\mathrm{Mg}$ and $\mathrm{Ca}$ excretion and alkalinised urine $\mathrm{pH}$ (up to 8). In parallel, citraturia was strongly increased, together with 2-ketoglutarate excretion, by potassium bicarbonate or malate in the diet. Basal sulfate excretion, in the range of $1 \mathrm{mmol} / \mathrm{d}$, was slightly enhanced in rats fed the potassium malate diet. The present model of low-grade metabolic acidosis indicates that potassium malate may be as effective as $\mathrm{KHCO}_{3}$ to counteract urine acidification, to limit divalent cation excretion and to ensure high citrate concentration in urine.
\end{abstract}

Low-grade acidosis: Potassium: Magnesium: Malate: Sulfate

Western diets are generally excessive in protein and $\mathrm{NaCl}$ and also frequently deficient in fruit and vegetables. Protein sulfur amino acids catabolism results in $\mathrm{SO}_{4}$ production, which is essentially eliminated through renal excretion (Bella \& Stipanuk, 1995; Nakamura et al. 2002). Homeostatic systems may act to buffer excess dietary acid load, namely $\mathrm{Ca}$ mobilisation from bone (Barzel, 1995; Frassetto et al. 2001; New, 2002) or glutamine catabolism in kidneys, which yields $\mathrm{HCO}_{3}{ }^{-}$transferred to plasma together with $\mathrm{NH}_{4}{ }^{+}$ions released in urine (Halperin et al. 1990). However, long-term periods of low-grade metabolic acidosis will lead to significant bone Ca wasting in rats and man (Won et al. 1996; Marangella et al. 2004), as well as to shift muscle protein metabolism towards proteolysis (Greiber \& Mitch, 1992; Bushinsky, 1995). These effects contribute to worsen the propensity to osteoporosis and osteopenia; all the more since the kidney's ability to excrete a dietary acid load is impaired with ageing (Frassetto et al. 1996; New, 2002).

A substantial part of $\mathrm{KHCO}_{3}$ used by the kidneys to neutralise fixed acidity arises from oxidation in tissues, especially in the splanchnic area, of K organic anions found in substantial amounts in fruits and vegetables. Citrate and malate anions are present in relatively similar amounts in portions of usually consumed fruits and vegetables, where they are partly neutralised by $\mathrm{K}$ and $\mathrm{Mg}$; typically less than $50 \%$ in fruits (down to $5 \%$ in citrus) but $70-90 \%$ in vegetables (Demigné et al. 2004a). Relatively few studies have addressed the respective importance of $\mathrm{K}$ and organic anions (such as citrate or malate) in the effects of plant foods on acidbase status and metabolism, especially mineral homeostasis, whereas there are reports supporting the interest of $\mathrm{K}$ itself as a protective element (He \& McGregor, 2001; Demigné et al. 2004b).

To further investigate this domain, models of low-grade metabolic acidosis in experimental animals are still scarce and it must be noted that most of usual rat diets, especially those based on AIN93 recommendations, may be considered as overprotective in this respect (Ward et al. 2003). In fact, the composition of their mineral moiety (especially major cations) is more reminiscent of the ancestral human diet (high in $\mathrm{K}$, poor in $\mathrm{Na}$ and rich in $\mathrm{Ca}$ and organic anions such as citrate) than of Western diets (with opposite characteristics). This type of rat diet leads to alkaline urine $\mathrm{pH}$ and moderate $\mathrm{Ca}$ and $\mathrm{Mg}$ excretion, and is a poorly suitable model to evaluate the effectiveness of high- $\mathrm{K}$ foods, such as fruits or vegetables. To address this problem, a model of a Westernised rat diet was designed and evaluated, and its responsiveness to supplementation with different $\mathrm{K}$ salts (chloride, bicarbonate or malate) was assessed.

\section{Materials and methods \\ Preparation of rat diets}

The control diet contained $200 \mathrm{~g}$ casein/kg (Louis François Cie, Saint-Maur, France) and $10 \mathrm{~g}$ methionine $/ \mathrm{kg}, 100 \mathrm{~g}$ fat $/ \mathrm{kg}$ (maize 
oil-groundnut oil; 50:50, w/w), $150 \mathrm{~g}$ sucrose $/ \mathrm{kg}, 15 \mathrm{~g} \mathrm{NaCl} / \mathrm{kg}$, $16.8 \mathrm{~g} \mathrm{CaH}\left(\mathrm{PO}_{4}\right) 2\left(\mathrm{H}_{2} \mathrm{O}\right) / \mathrm{kg}, 5 \mathrm{~g} \mathrm{MgSO}_{4}\left(7 \mathrm{H}_{2} \mathrm{O}\right) / \mathrm{kg}, 4.8 \mathrm{~g} \mathrm{KCl} / \mathrm{kg}$ (Sigma, St Louis, MO, USA), $10 \mathrm{~g}$ trace element mix/kg (AIN93M; Bethlehem, PA, USA), $10 \mathrm{~g}$ vitamin $\mathrm{mix} / \mathrm{kg}$ (AIN-76A; Bethlehem, PA, USA) and wheat starch quantum satis to make up to $1000 \mathrm{~g}$ (here $478 \mathrm{~g} / \mathrm{kg}$ ). High-K diets were prepared on the same basis as the control diet, by adding either $38.2 \mathrm{~g} \mathrm{KCl} / \mathrm{kg}$ ( $\mathrm{KCl}$ diet), $51.8 \mathrm{~g} \mathrm{KHCO}_{3} / \mathrm{kg}$ (potassium bicarbonate diet) or $50 \mathrm{~g}$ potassium malate $/ \mathrm{kg}$ (potassium malate diet), at the expense of wheat starch. The concentrations of $\mathrm{Na}, \mathrm{Ca}$ and $\mathrm{Mg}$ in all diets were $5.9,4.0$ and $0.5 \mathrm{~g} / \mathrm{kg}$, respectively. Dietary $\mathrm{K}$ concentration was either $2.5 \mathrm{~g} / \mathrm{kg}$ (control diet) or $20 \mathrm{~g} / \mathrm{kg}$ (high-K diets).

\section{Animals and sampling procedures}

Male Wistar rats (IFFA/CREDO, L'Arbresle, France) weighing approximately $180 \mathrm{~g}$ were randomly allocated to four groups of eight rats and fed one of the four semi-purified diets distributed as a moistened powder for $21 \mathrm{~d}$. The rats were housed in wirebottomed cages, and maintained in temperature-controlled rooms $\left(22^{\circ} \mathrm{C}\right)$ with a dark period from 20.00 to 08.00 hours and free access to food during the dark period. Body weight was recorded on days $0,7,14$, and 21 of the experiment; food intake determination and collection of urine were performed on four consecutive days at the end of the experiment. Rats were maintained and handled according to the recommendations of the Institut Nationale de la Recherche Agronomique Ethics Committee, in accordance with regional decree no. 87-848.

At the time of sampling ( 09.00 hours), rats were anaesthetised with sodium pentobarbital $(40 \mathrm{mg} / \mathrm{kg})$ and maintained on a plate at $37^{\circ} \mathrm{C}$. Blood was drawn from the abdominal aorta into a heparinised syringe and plasma was obtained after centrifugation at $10000 \mathrm{~g}$ for $2 \mathrm{~min}$. Plasmas were stored at $-20^{\circ} \mathrm{C}$ until analysis. After sampling, the rats were killed by an overdose of sodium pentobarbital.

\section{Analytical procedures}

Glucose, lactate, ammonia and urea were measured by enzymic procedures as previously described (Rémésy et al. 1978). Enzymes and coenzymes were purchased from Sigma (St Louis, MO, USA). $\mathrm{Na}$ and $\mathrm{K}$ in plasma and urine were quantified by flame photometry (PH90/ISA, Pouilly, France) and a PE560 atomic absorption spectrometer (Perkin Elmer, St-Quentin-en-Yvelines, France) was used for $\mathrm{Ca}$ and $\mathrm{Mg}$ measurements.
For analysis of urine anions, urine was 400-fold diluted with milli-Q water and analysed using a DX320 Dionex chromatograph (Dionex, Sunnyvale, CA, USA). Plasma samples were deproteinised by 4 volumes of methanol and then 50 -fold diluted with milli-Q water. The anions were separated on a $4 \times 250 \mathrm{~mm}$ AS 11 column/AG 11 pre-column (flow rate $1 \mathrm{ml} / \mathrm{min}$ ). An EG40 eluent generator controlled elution by an $\mathrm{OH}^{-}$gradient $(0.5$ to $35 \mathrm{mmol} / 1$ in $20 \mathrm{~min})$ and the conductimetry detector was preceded by an ASRS self-regenerating suppressor. Peaks were identified and quantified by comparison with pure anion standards (Dionex).

\section{Statistical analysis}

Values are given as means with their standard errors and significance of differences $(P<0.05)$ between mean values was determined by ANOVA coupled with the Student's Newman-Keuls' test.

\section{Results}

Food intake, weight gain and urine parameters

Food intake was about $17 \mathrm{~g} / \mathrm{d}$ except in the $\mathrm{KCl}$ diet group, which exhibited a lower intake, and hence a slightly lower energy intake (Table 1). Daily weight gain was significantly reduced in rats fed the $\mathrm{K}$ salts, especially in the $\mathrm{KCl}$ group, but when corrected for the energy density of the different diets $(5 \%$ less than the basal diet with the K-salt diets) the differences were no longer significant. Daily urine excretion, $15.7 \mathrm{ml} / \mathrm{d}$ in controls, was markedly elevated in rats fed the $\mathrm{KCl}$ diet and, to a lesser extent, in those fed the $\mathrm{KHCO}_{3}$ diet. Urine $\mathrm{pH}$ was acidic (about 5.5) in rats adapted to the control diet as well as to the $\mathrm{KCl}$ diet, whilst it was alkaline in rats fed the $\mathrm{KHCO}_{3}$ or potassium malate diets (in the range of $7 \cdot 7-8.05)$. Urine total $\mathrm{N}$ excretion $(268 \mathrm{mg} / \mathrm{d}$ with the basal diet) was in the range of $300-360 \mathrm{mg} / \mathrm{d}$ in rats adapted to the K diets (NS).

\section{Plasma metabolites and minerals}

As shown in Table 2, arterial plasma concentrations of glucose, lactate, $\mathrm{Na}, \mathrm{K}$ and $\mathrm{Mg}$ were not significantly altered by the diet conditions. There was a trend towards a slightly higher calcaemia in rats fed the alkalinising $\mathrm{K}$ diets, especially the potassium malate diet $(P<0 \cdot 01)$. Plasma urea was significantly higher in rats fed the $\mathrm{K}$ diets than in controls, but there was no significant difference between the $\mathrm{K}$ diet groups. Plasma sulfate

Table 1. Daily food intake, weight gain and urinary parameters (eight rats per group) (Mean values with their standard errors)

\begin{tabular}{|c|c|c|c|c|c|c|c|c|}
\hline & \multicolumn{2}{|c|}{ Control diet } & \multicolumn{2}{|c|}{$\mathrm{KCl}$ diet } & \multicolumn{2}{|c|}{$\mathrm{KHCO}_{3}$ diet } & \multicolumn{2}{|c|}{ Potassium malate diet } \\
\hline & Mean & SEM & Mean & SEM & Mean & SEM & Mean & SEM \\
\hline Weight gain $(g / d)$ & 6.04 & 1.34 & $5 \cdot 14$ & 1.40 & $5 \cdot 54$ & $1 \cdot 33$ & $5 \cdot 35$ & $1 \cdot 29$ \\
\hline FCE & 0.35 & & 0.33 & & 0.31 & & 0.32 & \\
\hline Urine excretion (ml/d) & $15 \cdot 7$ & $2 \cdot 1$ & $27 \cdot 9^{\star}$ & 3.2 & 21.9 & $2 \cdot 2$ & $23 \cdot 5^{\star}$ & $2 \cdot 1$ \\
\hline Urine $\mathrm{N}$ excretion $(\mathrm{mg} / \mathrm{d})$ & 268 & 30 & 363 & 42 & 300 & 26 & 364 & 35 \\
\hline
\end{tabular}

FCE, food conversion efficiency ( $g$ weight gain/g food intake).

Mean value was significantly different from that for the control condition $\left({ }^{\star} P<0.05\right)$. 
Table 2. Arterial plasma concentration of glucose, lactate, urea and minerals (eight rats per group)

(Mean values with their standard errors)

\begin{tabular}{|c|c|c|c|c|c|c|c|c|}
\hline & \multicolumn{2}{|c|}{ Control diet } & \multicolumn{2}{|c|}{$\mathrm{KCl}$ diet } & \multicolumn{2}{|c|}{$\mathrm{KHCO}_{3}$ diet } & \multicolumn{2}{|c|}{ Potassium malate diet } \\
\hline & Mean & SEM & Mean & SEM & Mean & SEM & Mean & SEM \\
\hline L-Lactate $(\mathrm{mmol} / \mathrm{l})$ & $2 \cdot 51$ & 0.28 & 2.42 & 0.14 & $2 \cdot 53$ & 0.12 & $2 \cdot 28$ & 0.08 \\
\hline Urea $(\mathrm{mmol} / \mathrm{l})$ & $6 \cdot 51$ & 0.30 & $8.79^{*}$ & 0.70 & $9.95^{*}$ & 0.48 & $9 \cdot 15^{*}$ & 0.64 \\
\hline Sulfate $(\mathrm{mmol} / \mathrm{l})$ & 1.35 & 0.36 & $1 \cdot 13$ & 0.29 & 1.37 & 0.40 & 1.61 & 0.38 \\
\hline $\mathrm{Na}(\mathrm{mmol} / \mathrm{l})$ & 143 & 5 & 148 & 6 & 142 & 5 & 146 & 3 \\
\hline $\mathrm{Ca}(\mathrm{mmol} / \mathrm{l})$ & $2 \cdot 36$ & 0.07 & $2 \cdot 48$ & 0.03 & $2 \cdot 56^{*}$ & 0.03 & $2.59^{*}$ & 0.03 \\
\hline $\mathrm{Mg}(\mathrm{mmol} / \mathrm{l})$ & $1 \cdot 35$ & 0.04 & 1.29 & 0.02 & $1 \cdot 21$ & 0.06 & $1 \cdot 36$ & 0.03 \\
\hline
\end{tabular}

Mean value was significantly different from that for the control condition $\left({ }^{\star} P<0.05\right)$.

concentration was in the range of $1.1-1.6 \mathrm{mmol} / \mathrm{l}$ and was not significantly altered by diet conditions.

\section{Urinary cation and anion excretion}

The results of cation analysis are shown in Figs. 1 and 2. Na excretion was about $4 \mathrm{mmol} / \mathrm{d}$ with all the diets whereas $\mathrm{K}$ excretion was practically 10 -fold greater in rats fed the high-K diets than in controls accounting for the near-totality of $\mathrm{K}$ intake in rats fed the high- $\mathrm{K}$ diets. In contrast, there was a difference between $\mathrm{K}$ intake and $\mathrm{K}$ excretion in rats fed the control diet (excreted $0.85 \mathrm{mmol} / \mathrm{d} v .1 .1 \mathrm{mmol} / \mathrm{d}$ ingested). Urine $\mathrm{Mg}$ excretion in rats fed the control or the $\mathrm{KCl}$ diet was much greater $(0 \cdot 16-0.18 \mathrm{mmol} / \mathrm{d})$ than in rats fed the alkalinising $\mathrm{K}$ diets $(0.02-0.04 \mathrm{mmol} / \mathrm{d})$. As a result, $\mathrm{Mg}$ excretion represented about $50 \%$ of the daily intake in rats fed the control or $\mathrm{KCl}$ diets, compared with $6-12 \%$ in those fed the alkalinising diets. $\mathrm{Ca}$ excretion in control rats was $0.36 \mathrm{mmol} / \mathrm{d}$, much lower than that observed in rats fed the $\mathrm{KCl}$ diet (mean $0.93 \mathrm{mmol} / \mathrm{d}$, with individual values peaking at $1.4 \mathrm{mmol} / \mathrm{d}$ ). Ca excretion was reduced by the $\mathrm{KHCO}_{3}$ and potassium malate diets, the $\mathrm{KHCO}_{3}$ diet appearing more effective in this respect. It must be noted that urine $\mathrm{Ca}$ excretion represents a minute fraction of $\mathrm{Ca}$ intake, $2 \%$ on average, except in rats fed the $\mathrm{KCl}$ diet (about $6 \%$ ). Calculated $\mathrm{H}^{+}$excretion (see Equation 1) was about $50 \mu \mathrm{mol} / \mathrm{d}$ in controls and $100 \mu \mathrm{mol} / \mathrm{d}$ in rats fed the $\mathrm{KCl}$ diet, compared with less than $1 \mu \mathrm{mol} / \mathrm{d}$ in rats fed the $\mathrm{KHCO}_{3}$ or potassium malate diets. In parallel, ammonium excretion was maximal in rats fed the control diet, and still noticeable in those adapted to the $\mathrm{KCl}$ diet, whereas it was strongly reduced in rats fed the $\mathrm{KHCO}_{3}$ and potassium malate diets.

$$
\left(10^{(-\mathrm{pH})} \times 10^{6}\right) \times(\text { urine flow in } \mathrm{ml} / 24 \mathrm{~h})
$$

Results of anion analysis in Figs. 3 and 4 show that chloride excretion was in the range of $5-6 \mathrm{mmol} / \mathrm{d}$ in control rats or rats fed the $\mathrm{KHCO}_{3}$ or potassium malate diet, and about $13 \mathrm{mmol} / \mathrm{d}$ in rats adapted to the $\mathrm{KCl}$ diet. Due to a relatively high provision of sulfur amino acids, there was a substantial excretion of sulfate in urine (about $0.9 \mathrm{mmol} / \mathrm{d}$ ); sulfate excretion was significantly higher $(1.3 \mathrm{mmol} / \mathrm{d})$ in rats fed the potassium malate diet. Phosphate excretion in the present experiment was not particularly responsive to alkalinising conditions (maximal in rats fed the $\mathrm{KCl}$ diet). Citrate and 2-ketoglutarate excretion proved extremely sensitive to acid-base conditions. Both anions were undetectable in urine under acidic $\mathrm{pH}$ conditions; they were excreted at a substantial rate in rats fed the $\mathrm{KHCO}_{3}$ and potassium malate diets but 2-ketoglutarate excretion (on a molar basis) was lower than that of citrate. Oxalate excretion was in the $\mu \mathrm{mol} / \mathrm{d}$ range; in contrast to citrate or 2-ketoglutarate, it was maximal in control conditions and markedly depressed with the high-K diets, especially the potassium malate diet.
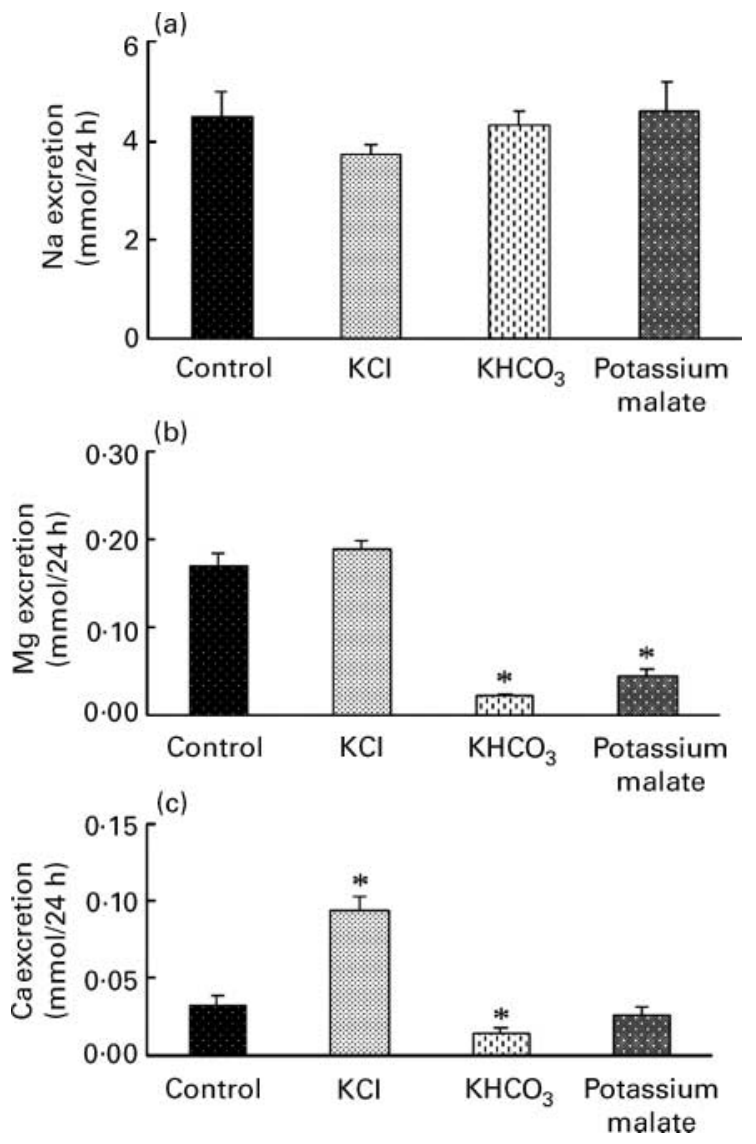

Fig. 1. Urinary excretion of $\mathrm{Na}(\mathrm{a}), \mathrm{Mg}(\mathrm{b})$ and $\mathrm{Ca}$ (c) in rats adapted to a control acidogenic diet or diets supplemented with various $\mathrm{K}$ salts $\left(\mathrm{Cl}, \mathrm{HCO}_{3}\right.$ or malate). Values are means for eight rats per group $(\mathrm{mmol} / 24 \mathrm{~h})$, with their standard errors represented by vertical bars. Urine was collected over four consecutive days before rat slaughter and pooled. Mean value was significantly different from that for the control condition $\left({ }^{\star} P<0.05\right)$. 
(a)

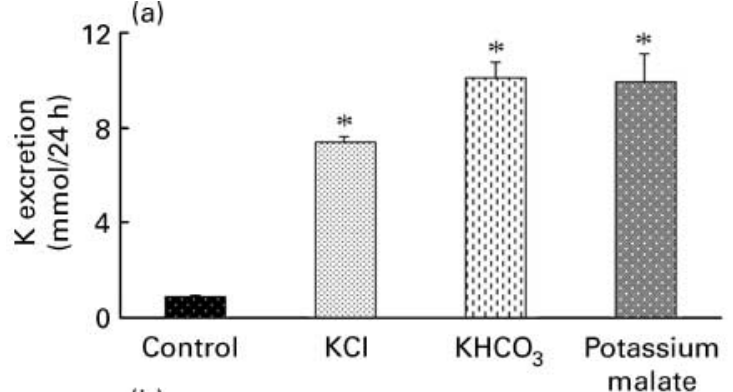

(b)

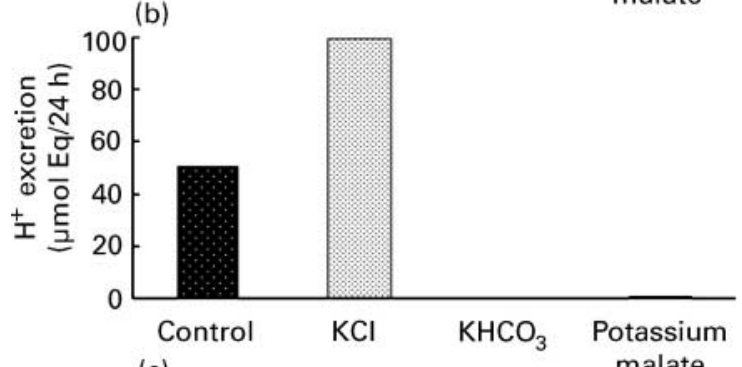

(c)

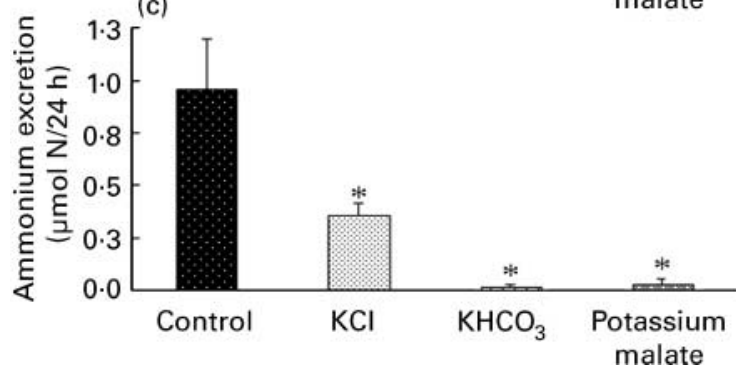

Fig. 2. Urinary excretion of $\mathrm{K}(\mathrm{a})(\mathrm{mmol} / 24 \mathrm{~h}), \mathrm{H}^{+}$(b) and ammonium (c) $(\mu \mathrm{mol} / 24 \mathrm{~h})$ in rats adapted to a control acidogenic diet or diets supplemented with various $\mathrm{K}$ salts $\left(\mathrm{Cl}, \mathrm{HCO}_{3}\right.$ or malate). Values are means for eight rats per group, with their standard errors represented by vertical bars. Urine was collected over four consecutive days before rat slaughter and pooled. Mean value was significantly different from that for the control condition ( $\left.{ }^{\star} P<0.05\right)$.

\section{Discussion}

The characteristics of the present acidogenic diet are typical of the so-called Western diet and probably provide a more physiological model of latent acidosis than, for example, addition of $\mathrm{NH}_{4} \mathrm{Cl}$ in drinking water, which is effective in providing an overload of hydrogen ions but also profoundly disturbs $\mathrm{N}$ metabolism (Cheema-Dhadli et al. 1987). Dietary protein intake in excess of maintenance requirements generates a substantial fixed acidity, namely $\mathrm{SO}_{4}{ }^{2-}$, as a result of sulfur amino acid catabolism (Remer, 2000). Methionine supplementation itself is an effective mean to increase urinary net acid excretion as $\mathrm{SO}_{4}{ }^{2-}$ (Remer \& Manz, 1994). The present results suggest that increasing dietary $\mathrm{K}$ is not effective against acidosis in the form of the $\mathrm{Cl}$ salt, as previously reported (Morris et al. 1999). In fact, acidosis may even be more pronounced with $\mathrm{KCl}$ in the diet, as reflected by the very high rate of $\mathrm{Mg}, \mathrm{Ca}$ or $\mathrm{H}^{+}$excretion. This point is noteworthy since $\mathrm{KCl}$ is frequently proposed as a substitute of $\mathrm{NaCl}$ in dietetic interventions aiming at lowering blood pressure and the risk of stroke (Gilleran et al. 1996). Some previous studies support the view that $\mathrm{KCl}$ loading could decrease acid excretion, but to a lesser extent than $\mathrm{KHCO}_{3}$, and an indirect effect of $\mathrm{K}$ on $\mathrm{H}^{+}$excretion has been postulated (van Buren et al. 1992). Nevertheless, it must be kept in mind that
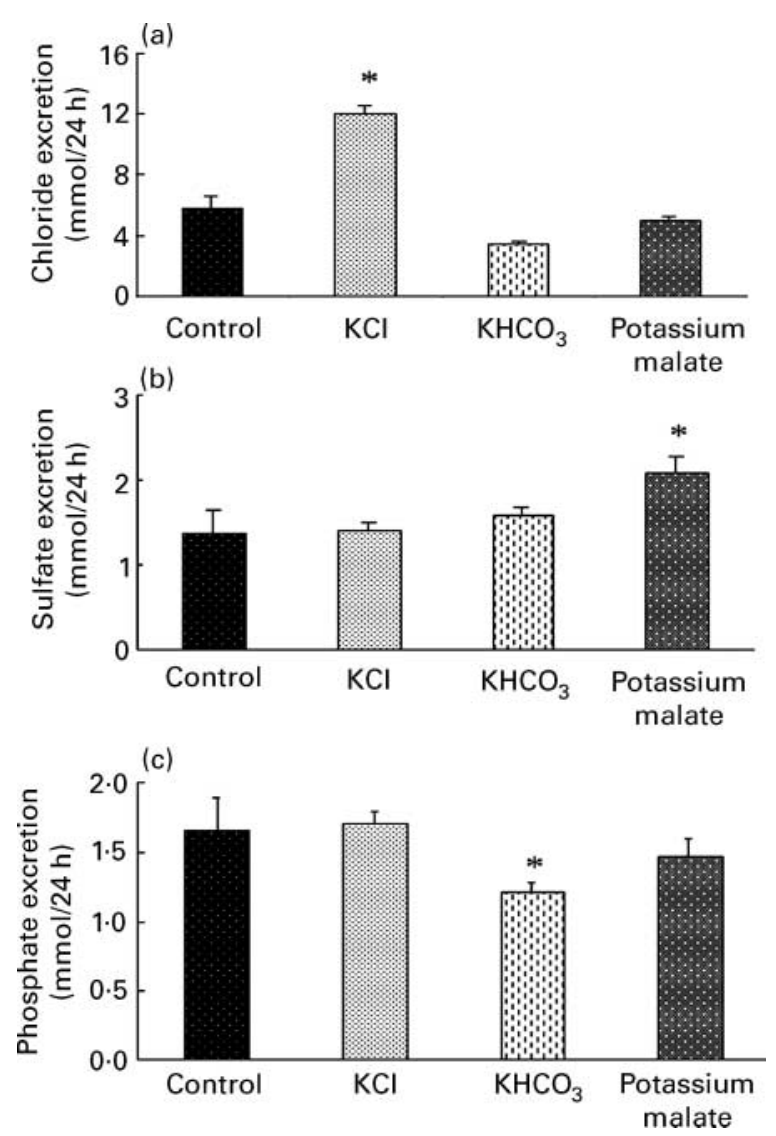

Fig. 3. Urinary excretion of chloride (a), sulfate (b) and phosphate (c) in rats adapted to a control acidogenic diet or diets supplemented with various $\mathrm{K}$ salts $\left(\mathrm{Cl}, \mathrm{HCO}_{3}\right.$ or malate). Values are means for eight rats per group $(\mathrm{mmol} / 24 \mathrm{~h})$, with their standard errors represented by vertical bars. Urine was collected over four consecutive days before rat slaughter and pooled. Mean value was significantly different from that for the control condition $\left({ }^{\star} P<0.05\right)$.

investigations in this domain have seldom been carried out in acidotic models.

In contrast to $\mathrm{KCl}, \mathrm{KHCO}_{3}$ or potassium malate were effective in alkalinising urine and counteracting various adverse effects of lowgrade acidosis such as excessive $\mathrm{Ca}$ and $\mathrm{Mg}$ elimination, or hypocitraturia. Various $\mathrm{Na}^{+}$-dependent dicarboxylate transporters (for succinate, 2-ketoglutarate and probably malate) have been identified in the digestive tract, with $\mathrm{K}_{\mathrm{m}}$ for substrates ranging from about $1 \mathrm{mmol} / \mathrm{l}$ down to less than $100 \mu \mathrm{mol} / \mathrm{l}$ (Pajor, 1999). The intestine plays a major role for malate or citrate absorption and metabolism (Wolffram et al. 1994; Pajor, 1999), which yields $\mathrm{CO}_{2}$ or other intermediate metabolites such as amino acids (alanine, proline, etc) or lactate. In the liver the removal of circulating dicarboxylates involves at least two transport systems; a $\mathrm{Na}^{+}-$ dicarboxylate symport and a system of anion exchange (Zimmerli et al. 1992). Organic anions are then channelled in different metabolic pathways: (i) direct oxidation to $\mathrm{CO}_{2}$; (ii) incorporation into glucose and liver glycogen; or (iii) use for glutamine synthesis in perivenous hepatocytes (Stoll et al. 1991).

In control or $\mathrm{KCl}$-fed rats, the percentage of ingested $\mathrm{Mg}$ excreted by the kidneys was high (about $50 \%$ ). Considering that the percentage of $\mathrm{Mg}$ absorption in normal rats is about 70 (Coudray et al. 2002), there was certainly a very poor Mg retention in acidotic rats in contrast to rats fed alkalinising $\mathrm{K}$ diets. It is 

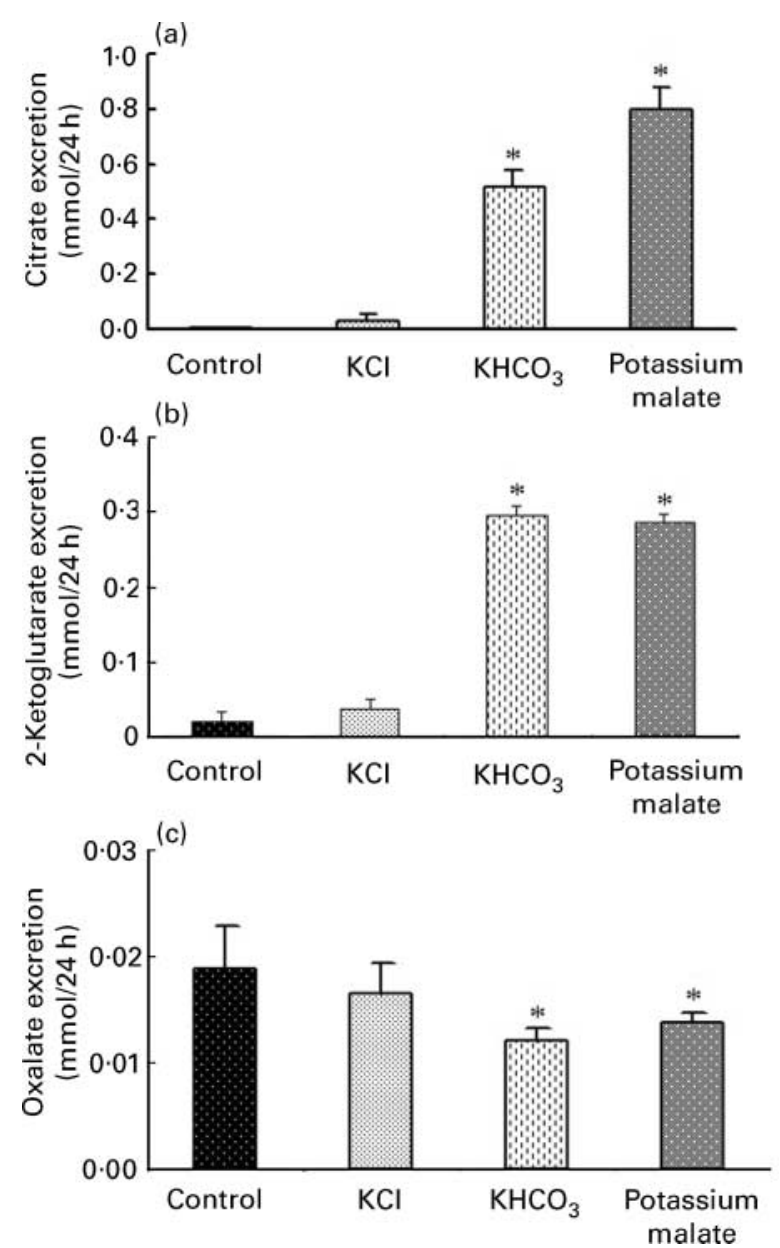

Fig. 4. Urinary excretion of citrate (a), 2-ketoglutarate (b) and oxalate (c) in rats adapted to a control acidogenic diet or diets supplemented with various $\mathrm{K}$ salts $\left(\mathrm{Cl}, \mathrm{HCO}_{3}\right.$ or malate). Values are means for eight rats per group $(\mathrm{mmol} / 24 \mathrm{~h})$, with their standard errors represented by vertical bars. Urine was collected over four consecutive days before rat slaughter and pooled. Mean value was significantly different from that for the control condition $\left({ }^{\star} P<0 \cdot 05\right)$.

well established that metabolic acidosis is associated with urinary $\mathrm{Mg}$ wasting, possibly due to a direct effect of $\mathrm{H}$ on distal $\mathrm{Mg}$ transport (Dai et al. 1997; Quamme, 1997). In spite of the large fluctuations of renal $\mathrm{Mg}$ excretion, plasma $\mathrm{Mg}$ concentration was extremely constant. However, since extracellular $\mathrm{Mg}$ represents less than $1 \%$ of the total $\mathrm{Mg}$ pool, it remains to be assessed if the changes observed in the present study had any significant influence on the intracellular Mg activity (Ryan, 1993). $\mathrm{Ca}$ excretion represents a minute percentage of $\mathrm{Ca}$ supplied by the diets (presently $1-2 \%$ ) except in rats fed the $\mathrm{KCl}$ diet (about $6 \%$ ). Rat diets are frequently rich in $\mathrm{Ca}(4 \mathrm{~g} / \mathrm{kg}$ in the present experiment), and since $\mathrm{Ca}$ absorption is subjected to a tight regulation, the observed excretion of $\mathrm{Ca}$ could represent a relatively substantial part of absorbed $\mathrm{Ca}$. In this view, calcaemia was significantly lower in rats fed the control or $\mathrm{KCl}$ diets than in rats fed the alkalinising diets. Conceivably, rats fed these last diets had a normal calcaemia whereas acidotic rats were relatively hypocalcaemic. The comparison between $\mathrm{Ca}$ and $\mathrm{Mg}$ excretion in the present experiment suggests that $\mathrm{Mg}$ may play a substantial role, besides $\mathrm{Ca}$, in the compensation of low-grade metabolic acidosis (in the short term at least).
It is noteworthy that the alkalinising diets slightly enhanced $\mathrm{SO}_{4}{ }^{2-}$ excretion. Metabolic acidosis has been shown to reduce $\mathrm{SO}_{4}{ }^{2-}$ reabsorption in the kidneys (Puttaparthi et al. 1999) as well as chronic renal failure, which depresses $\mathrm{Na}^{+} / \mathrm{SO}_{4}{ }^{2-}$ co-transport $(\mathrm{NaSi})$ and $\mathrm{SO}_{4}{ }^{2-}$ /oxalate ${ }^{\mathrm{n}-}-\mathrm{HCO}_{3}{ }^{-}$exchanger (Sat-1) (Fernandes et al. 2001). On this basis, alkalinising agents might restore $\mathrm{SO}_{4}{ }^{2-}$ reabsorption through a reversal of transporter down regulation by acidosis and possibly through provision of $\mathrm{HCO}_{3}{ }^{-}$for the $\mathrm{SO}_{4}{ }^{2-}$ /anion exchanger. In fact, the greater rate of $\mathrm{SO}_{4}{ }^{2-}$ excretion in rats fed the alkalinising diets suggests that its reabsorption, whether activated or not, could not match an increased generation of $\mathrm{SO}_{4}{ }^{2-}$. Other sulfur metabolism endproducts have not been measured, such as taurine, but they generally represent a minor part of total sulfur catabolism (Nakamura et al. 2002).

Phosphate is the major buffer system in urine and its excretion is generally increased during acidosis, as a result of a decrease of the preferentially transported form $\left(\mathrm{HPO}_{4}{ }^{2-}\right)$, together with a direct effect of $\mathrm{pH}$ on the apical phosphate carrier in the proximal tubule (Ambuhl et al. 1998). This response to acidosis was not apparent in the present experiment, possibly a reflection of the high level of phosphate in the rat diets (also a feature of Western diets). Citrate transport is also frequently analysed owing to its sensitivity to systemic $\mathrm{pH}$; citrate excretion is altered by changes in the transported chemical form, namely citrate ${ }^{2-}$, and in kidney metabolism (Brennan et al. 1986). It is now well established that acidosis promotes hypocitraturia and the tubular reabsorption of citrate. In rats, in parallel to hypocitraturia, chronic acidosis increases the cortical activity of ATP citrate lyase (ACL); abundance of the ACL protein in the renal cortex may be dramatically enhanced within a few days, but with little change in ACL mRNA (Melnick et al. 1996). Hypokaliaemia also promotes hypocitraturia and a rise of ACL activity. In the rat, chronic metabolic acidosis and $\mathrm{K}$ deficiency also raises aconitase activity and, conversely, alkalinising agents in the diet may slightly depress its activity (Melnick et al. 1998). In parallel, activity of the apical $\mathrm{Na}^{+}$/citrate co-transporter is enhanced by metabolic acidosis in the kidneys, but seems unresponsive to the addition of alkalinising agents in the diet (Aruga et al. 2000). The renal excretion of citrate is normally dependent on the net absorption of alkali from the digestive tract (Sakhaee et al. 1993), but this relationship is less tight in subjects suffering distal renal tubular acidosis. In this view, it has been proposed that 'low vegetable fibre intake and low urine volume' could be added to the list of risk factors for low urine citrate (Hess et al. 1994). 2-Ketoglutarate also represents a noticeable contribution to anion excretion, although less than that of citrate. Kidneys exhibit substantial capacities of 2-ketoglutarate metabolism and transport (Burckhardt \& Burckhardt, 2003) and it has been shown that acute metabolic acidosis has little effect on renal handling of 2-ketoglutarate, whereas alkalosis results in the addition of 2-ketoglutarate by the renal cells both to blood and luminal fluid (Martin et al. 1989).

In conclusion, the present study proposes a model of low-grade metabolic acidosis of dietary origin in the rat. This model is responsive to dietary $\mathrm{K}$ manipulations and it establishes that, for example, potassium malate is practically as potent as potassium bicarbonate in exerting alkalinising effects. The present experiment raises questions about the actual effects of $\mathrm{K}$ organic salts on protein metabolism, since effects of potassium malate on blood urea are in line with a role of hepatic urea synthesis as a pathway for the removal of metabolically generated bicarbonate (Häussinger, 1997) but are less consistent with the purported inhibition of proteolysis by alkalinising agents (Greiber \& Mitch, 
1992). Another noticeable observation is the fact that $\mathrm{Mg}$ shows the same responsiveness to urine acidification or alkalinisation as $\mathrm{Ca}$ and it would be interesting to assess whether $\mathrm{Mg}$, abundant in plant foods together with $\mathrm{K}$, is liable to spare $\mathrm{Ca}$ in case of metabolic acidosis.

\section{References}

Ambuhl PM, Zajicek HK, Wang H, Puttaparthi K \& Levi M (1998) Regulation of renal phosphate transport by acute and chronic metabolic acidosis in the rat. Kidney Int 53, 1288-1298.

Aruga S, Wehrli S, Kaissling B, Moe OW, Preisig PA, Pajor AM \& Alpern RJ (2000) Chronic metabolic acidosis increases NaDC-1 mRNA and protein abundance in rat kidney. Kidney Int 58, 206-215.

Barzel US (1995) The skeleton as an ion exchange system: implications for the role of acid-base imbalance in the genesis of osteoporosis. $J$ Bone Miner Res 10, 1431-1436.

Bella DL \& Stipanuk MH (1995) Effects of protein, methionine, or chloride on acid-base balance and on cysteine catabolism. Am J Physiol 269, E910-E917.

Brennan TS, Klahr S \& Hamm LL (1986) Citrate transport in rabbit nephron. Am J Physiol 251, F683-F689.

Burckhardt BC \& Burckhardt G (2003) Transport of organic anions across the basolateral membrane of proximal tubule cells. Rev Physiol Biochem Pharmacol 146, 95-158.

Bushinsky DA (1995) Stimulated osteoclastic and suppressed osteoblastic activity in metabolic but not respiratory acidosis. Am J Physiol $\mathbf{2 6 8}$, C80-C88.

Cheema-Dhadli S, Jungas RL \& Halperin ML (1987) Regulation of urea synthesis by acid-base balance in vivo: role of NH3 concentration. $\mathrm{Am}$ J Physiol 252, F221-F225.

Coudray C, Feillet-Coudray C, Grizard D, Tressol JC, Gueux E \& Rayssiguier Y (2002) Fractional intestinal absorption of magnesium is directly proportional to dietary magnesium intake in rats. $J$ Nutr 132, 2043-2047.

Dai LJ, Friedman PA \& Quamme GA (1997) Acid-base changes alter $\mathrm{Mg}^{2+}$ uptake in mouse distal convoluted tubule cells. Am J Physiol 272, F759-F766.

Demigné C, Sabboh H, Puel C, Rémésy C \& Coxam V (2004a) Organic anions potassium salts in nutrition and metabolism. Nutr Res Rev 17, 249-258.

Demigné C, Sabboh H, Rémésy C \& Meneton P (2004b) Protective effects of high dietary potassium: nutritional and metabolic aspects. $J$ Nutr 134, 2903-2906.

Fernandes I, Laouari D, Tutt P, Hampson G, Friedlander G \& Silve C (2001) Sulfate homeostasis, NaSi-1 cotransporter, and SAT-1 exchanger expression in chronic renal failure in rats. Kidney Int 59, 210-221.

Frassetto L, Morris RC Jr, Sellmeyer DE, Todd K \& Sebastian A (2001) Diet, evolution and aging - the pathophysiologic effects of the postagricultural inversion of the potassium-to-sodium and base-to-chloride ratios in the human diet. Eur J Nutr 40, 200-213.

Frassetto LA, Morris RC \& Sebastian A (1996) Effect of age on blood acid-base composition in adult humans: role of age-related renal function decline. Am J Physiol 271, F1114-F1122.

Gilleran G, O'Leary M, Bartlett WA, Vinall H, Jones AF \& Dodson PM (1996) Effects of dietary sodium substitution with potassium and magnesium in hypertensive type II diabetics: a randomised blind controlled parallel study. J Hum Hypertens 10, 517-521.

Greiber S \& Mitch WE (1992) Mechanisms for protein catabolism in uremia: metabolic acidosis and activation of proteolytic pathways. Miner Electrolyte Metab 18, 233-236.

Halperin ML, Ethier JH \& Kamel KS (1990) The excretion of ammonium ions and acid-base balance. Clin Biochem 23, 185-188.
Häussinger D (1997) Liver regulation of acid-base balance. Miner Electrolyte Metab 23, 249-252.

He FJ \& McGregor GA (2001) Beneficial effects of potassium. Br Med J 323, 497-501.

Hess B, Michel R, Takkinen R, Ackermann D \& Jaeger P (1994) Risk factors for low urinary citrate in calcium nephrolithiasis: low vegetable fibre intake and low urine volume to be added to the list. Nephrol Dial Transplant 9, 642-649.

Marangella M, Di Stefano M, Casalis S, Berutti S, D’Amelio P \& Isaia GC (2004) Effects of potassium citrate supplementation on bone metabolism. Calcif Tissue Int 74, 330-335.

Martin M, Ferrier B \& Baverel G (1989) Transport and utilization of alphaketoglutarate by the rat kidney in vivo. Pflugers Arch 413, 217-224.

Melnick JZ, Preisig PA, Moe OW, Srere P \& Alpern RJ (1998) Renal cortical aconitase is regulated in hypo- and hypercitraturia. Kidney Int $\mathbf{5 4}$, $160-165$.

Melnick JZ, Srere PA, Elshourbagy NA, Moe OW, Preisig PA \& Alpern RJ (1996) Adenosine triphosphate citrate lyase mediates hypocitraturia in rats. $J$ Clin Invest 98, 2381-2387.

Morris RC Jr, Schmidlin O, Tanaka M, Forman A, Frassetto L \& Sebastian A (1999) Differing effects of supplemental $\mathrm{KCl}$ and KHCO3: pathophysiological and clinical implications. Semin Nephrol 19, 487-493.

Nakamura H, Kajikawa R \& Ubuka T (2002) A study on the estimation of sulfur-containing amino acid metabolism by the determination of urinary sulfate and taurine. Amino Acids 23, 427-431.

New SA (2002) Nutrition Society Medal lecture. The role of the skeleton in acid-base homeostasis. Proc Nutr Soc 61, 151-164.

Pajor AM (1999) Citrate transport by the kidney and intestine. Semin Nephrol 19, 195-200.

Puttaparthi K, Markovich D, Halaihel N, Wilson P, Zajicek HK, Wang H, Biber J, Murer H, Rogers T \& Levi M (1999) Metabolic acidosis regulates rat renal $\mathrm{Na}-\mathrm{Si}$ cotransport activity. Am $J$ Physiol 276, C1398-C1404.

Quamme GA (1997) Renal magnesium handling: new insights in understanding old problems. Kidney Int 52, 1180-1195.

Remer T (2000) Influence of diet on acid-base balance. Semin Dial 13, 221-226.

Remer T \& Manz F (1994) Estimation of the renal net acid excretion capacity: evidence that an increased protein intake improves the capacity of the kidney to excrete ammonium. J Nutr Biochem 6, 431-437.

Rémésy C, Demigné C \& Aufrère J (1978) Inter-organ relationships between glucose, lactate and amino acids in rats fed on high-carbohydrate or high-protein diets. Biochem J 170, 321-329.

Ryan MP (1993) Interrelationships of magnesium and potassium homeostasis. Miner Electrolyte Metab 19, 290-295.

Sakhaee K, Williams RH, Oh MS, Padalino P, Adams-Huet B, Whitson P \& Pak CY (1993) Alkali absorption and citrate excretion in calcium nephrolithiasis. J Bone Miner Res 8, 789-794.

Stoll B, McNelly S, Buscher HP \& Hässinger D (1991) Functionnal hepatocyte heterogeneity in glutamate, aspartate and alpha-ketoglutarate uptake: a histoautoradiography study. Hepatology 13, 247-253.

van Buren M, Rabelink TJ, van Rijn HK \& Koomans HA (1992) Effects of acute $\mathrm{NaCl}, \mathrm{KCl}$ and $\mathrm{KHCO} 3$ loads on renal electrolyte excretion in humans. Clin Sci 83, 567-574.

Ward WE, Kim S \& Robert Bruce W (2003) A western-style diet reduces bone mass and biomechanical bone strength to a greater extent in male compared to female rats during development. Br J Nutr 90, 589-595.

Wolffram S, Unternahrer R, Grenacher B \& Scharrer E (1994) Transport of citrate across the brush border and basolateral membrane of rat small intestine. Comp Biochem Physiol 109, 39-52.

Won JH, Fukuda S, Sato R \& Naito Y (1996) Bone histomorphometric changes due to differences in calcium intake under metabolic acidosis in rats. $J$ Vet Med Sci 58, 611-616.

Zimmerli B, O'Neill B \& Meier PJ (1992) Identification of sodium-dependent and sodium-independent dicarboxylate transport systems in rat liver basolateral membrane vesicles. Pflügers Arch 421, 329-335. 